\title{
Teaching NeuroImages: \\ Central neurocytoma
}

Matthew Smith-Cohn, DO

Paul A. House, MD

Yoshimi Anzai, MD, $\mathrm{MPH}$

Correspondence to

Dr. Smith-Cohn:

Matthew.Smith-Cohn@hsc.utah.edu

Figure $\quad$ CT and MRI scans of the brain show a central gangliocytoma
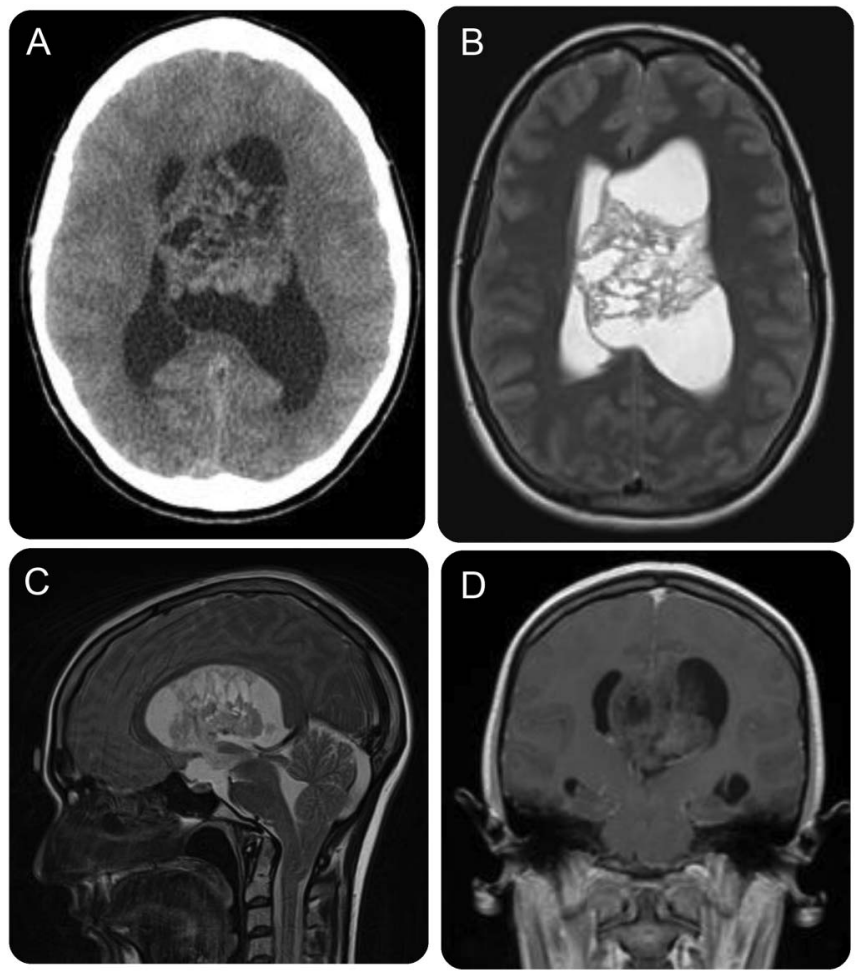

Axial ([A] axial CT without contrast, [B] axial T2-weighted MRI without contrast), sagittal ([C] sagittal T2-weighted MRI with contrast), and coronal ([D] coronal T1-weighted fast low-angle shot MRI with contrast) views show a $5 \times 5 \times$ 4-cm cystic mass resulting in hydrocephalus. Incidentally, an approximate 2 -cm displacement of the cerebellar tonsils is evident (C), consistent with a Chiari I malformation. The presentation of amenorrhea can be attributed radiographically to the increased intracranial pressure reflected by the enlarged suprasellar cistern and by the direct contact of the mass with the hypothalamus.

A woman in her mid-20s presented with a 6-month history of worsening headaches, amenorrhea, and nausea. Neurologic examination demonstrated word-finding difficulties, mild right-sided weakness of the upper and lower extremities, and mild rightsided neglect. Imaging revealed a complex, cystic, heterogeneously enhancing mass in the left lateral ventricle extending to the foramen of Monro (figure). Pathology after surgical resection was consistent with a central neurocytoma. This benign tumor, comprising $0.25 \%-0.5 \%$ of all brain tumors, typically affects young adults and arises from subependymal neural progenitor cells. Treatment consists of surgery and radiation therapy, and generally carries a favorable prognosis. ${ }^{1,2}$

\section{AUTHOR CONTRIBUTIONS}

Dr. Smith-Cohn: case report concept, design and critical revision of content, takes responsibility for the data, the analyses and interpretation, and the conduct of the case report. Dr. House: critical revision of the manuscript content. Dr. Anzai: critical revision of the manuscript content.

\section{ACKNOWLEDGMENT}

The authors thank Kristin Kraus, MSc, for technical editing.
Download teaching slides: Neurology.org
From the Departments of Neurology (M.S.-C.) and Neurosurgery (P.A.H.), Clinical Neurosciences Center, and the Department of Radiology and Imaging Sciences (Y.A.), University of Utah, Salt Lake City.

Go to Neurology.org for full disclosures. Funding information and disclosures deemed relevant by the authors, if any, are provided at the end of the article. 
STUDY FUNDING

No targeted funding reported.

\section{DISCLOSURE}

The authors report no disclosures relevant to the manuscript. Go to Neurology.org for full disclosures.
REFERENCES

1. Schmidt MH, Gottfried ON, von Koch CS, Chang SM, McDermott MW. Central neurocytoma: a review. J Neurooncol 2004;66:377-384.

2. Sim FJ, Keyoung HM, Goldman JE, et al. Neurocytoma is a tumor of adult neuronal progenitor cells. J Neurosci 2006; 26:12544-12555. 


\title{
Neurology
}

\author{
Teaching NeuroImages: Central neurocytoma \\ Matthew Smith-Cohn, Paul A. House and Yoshimi Anzai \\ Neurology 2017;89;e126-e127 \\ DOI 10.1212/WNL.0000000000004334
}

This information is current as of September 4, 2017

Updated Information \&
Services

Supplementary Material

References

Subspecialty Collections

Permissions \& Licensing

Reprints including high resolution figures, can be found at: http://n.neurology.org/content/89/10/e126.full

Supplementary material can be found at: http://n.neurology.org/content/suppl/2017/09/04/WNL.0000000000004 334.DC1

This article cites 2 articles, 1 of which you can access for free at: http://n.neurology.org/content/89/10/e126.full\#ref-list-1

This article, along with others on similar topics, appears in the following collection(s):

All Headache

http://n.neurology.org/cgi/collection/all_headache

All Imaging

http://n.neurology.org/cgi/collection/all_imaging

All Oncology

http://n.neurology.org/cgi/collection/all_oncology

Primary brain tumor

http://n.neurology.org/cgi/collection/primary_brain_tumor Surgical therapy-tumor

http://n.neurology.org/cgi/collection/surgical_therapytumor

Information about reproducing this article in parts (figures,tables) or in its entirety can be found online at:

http://www.neurology.org/about/about_the_journal\#permissions

Information about ordering reprints can be found online:

http://n.neurology.org/subscribers/advertise

Neurology ${ }^{\circledR}$ is the official journal of the American Academy of Neurology. Published continuously since 1951, it is now a weekly with 48 issues per year. Copyright @ 2017 American Academy of Neurology. All rights reserved. Print ISSN: 0028-3878. Online ISSN: 1526-632X.

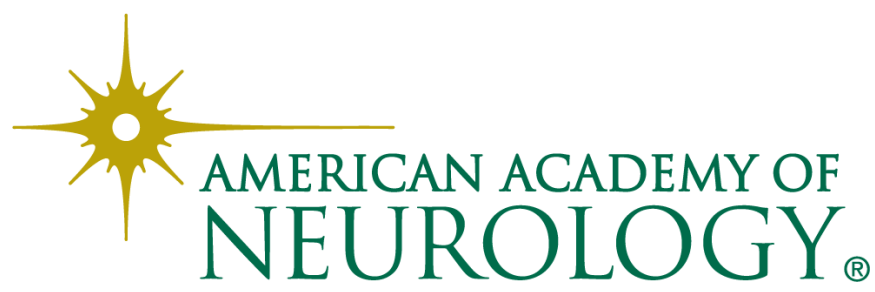

